\title{
Understanding convergent signaling regulation in metastatic breast cancer cells using a bioengineered stem cell microenvironment
}

\author{
Bridget Mooney, Yangzi Isabel Tian, Erin Rousseau, Yubing Xie \\ Colleges of Nanoscale Science and Engineering, SUNY Polytechnic Institute, Albany, NY 12203, USA.
}

Correspondence to: Prof. Yubing Xie, Colleges of Nanoscale Science and Engineering, SUNY Polytechnic Institute, 257 Fuller Road, Albany, NY 12203, USA. E-mail: YXie@sunypoly.edu

How to cite this article: Mooney B, Tian YI, Rousseau E, Xie Y. Understanding convergent signaling regulation in metastatic breast cancer cells using a bioengineered stem cell microenvironment. J Cancer Metastasis Treat 2019;5:19. http://dx.doi.org/10.20517/2394-4722.2018.93

Received: 8 Dec 2018 First Decision: 24 Jan 2019 Revised: 28 Jan 2019 Accepted: 12 Feb 2019 Published: 22 Mar 2019

Science Editor: William P. Schiemann Copy Editor: Cai-Hong Wang Production Editor: Huan-Liang Wu

\begin{abstract}
Aim: The convergence of tumorigenic and embryonic signaling pathways drives us to exploit the embryonic stem cell (ESC) microenvironment to restrict metastatic potential of cancer cells. We have previously demonstrated that bioengineered ESC microenvironments could restrict growth and metastatic potential of highly aggressive breast cancer cell (BCC). This study aims to further understand the regulation of convergent EGFR and canonical Wnt/ $\beta$-catenin signaling pathway function in triple negative metastatic BCCs using the 3D in vitro ESC microenvironment created by encapsulating ESCs in alginate hydrogel microstrands.
\end{abstract}

Methods: Co-culture with ESC-microstrands increased sensitivity to two chemotherapeutic drugs in metastatic $B C C s$. To test whether these changes were due to restored signaling pathway regulation in BCCs, we probed for changes in gene expression of key molecules related to the EGFR and canonical Wnt/ $\beta$-catenin signaling pathways using quantitative reverse transcription polymerase chain reaction and Western blot analysis.

Results: ESC-microstrands are able to alter the gene expression of highly aggressive BCCs at both mRNA and protein levels. These changes are indicative of a reversal of EGFR and canonical Wnt/ $\beta$-catenin signaling pathway hyperactivation following co-culture. Increased NKD2 mRNA and protein expression coinciding with dual signaling pathway inhibition within co-cultured BCCs suggests that this reversal may be attributable to restored regulation of NKD2 within these pathways.

Conclusion: ESC-microstrands are able to reverse oncogenic signaling pathway hyperactivation and restore signaling pathway regulation in metastatic BCCs. Further studies could provide insight into what role NKD2 up-regulation plays

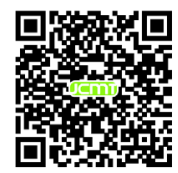


in BCC inhibition, leading to the development of a new targeted therapy for metastatic breast cancer.

Keywords: Metastasis, cancer cell, signaling, 3D culture, stem cells, EGFR, Wnt/ $\beta$-catenin, NKD2

\section{INTRODUCTION}

Human breast cancer is currently the highest diagnosed form of cancer and the second leading cause of cancer-related deaths in American women. Triple negative breast cancer is of the basal subtype and displays poor prognosis owing to its highly metastatic properties. Current treatments focused on eradicating breast tumors in lieu of or following local therapy include chemotherapy, hormonal therapy, and targeted therapy. Hormonal therapy is not an option for triple negative breast cancer as it does not contain hormone receptors, and there are currently no approved biological targeted therapies. Chemotherapy has proven unsuccessful because triple negative breast cancer is highly drug resistant and is associated with high toxicity ${ }^{[1]}$. It remains a huge challenge to fully understand the mechanisms of cell migration and invasion of cancer cells, such as triple negative breast cancer cells, and to eliminate these cancer cells to prevent disease recurrence and metastasis.

Metastatic breast cancer cells have been linked to embryonic stem cells (ESCs) due to their sharing of certain similar gene signatures and convergence of tumorigenic and embryonic pathways (e.g., EGFR, Wnt $/ \beta$-catenin, and TGF- $\beta)^{[2-4]}$. ESC microenvironments have been exploited to restrict metastatic potential of cancer cells ${ }^{[5-7]}$. In particular, our previous studies have shown that bioengineered 3D ESC microenvironments using alginate hydrogels have great potential to supply critical signaling molecules and reprogram highly aggressive breast cancer cells to a non-invasive phenotype $e^{[4,8-10]}$, including decreased cell proliferation, increased apoptosis, reduced cell migration, invasion and metastatic marker expression, reversed epithelial-mesenchymal transition (EMT), and altered cell metabolism of metastatic breast cancer cells. The engineering of unique ESC microenvironments in vitro which can restrict the metastatic potential of triple negative breast cancer cells (BCCs) may permit advanced study of cancer metastasis. Consequently, this could provide greater insight into the decision-making processes regarding the growth, migration, and invasion of cancer cells and its subsequent prevention.

The EGFR and canonical Wnt/ $\beta$-catenin signaling pathways control many cell properties that contribute to the metastatic phenotype. The EGFR (also known as the ErbB1/HER1) belongs to the ErbB family of tyrosine kinase receptors. Binding of ligands (e.g., EGF, TGF- $\alpha$ ) to the EGFR initiates dimerization of the EGFR with one of the other three receptors within the same family. Dimerization activates the intracellular tyrosine kinase domain, which undergoes autophosphorylation. This causes a conformational change which exposes the activation loop and allows for protein binding and phosphorylation of downstream signaling targets $^{[11,12]}$. Phosphorylation initiates signaling cascades, such as Ras/Raf/mitogen-activated protein kinase/ ERK, phosphoinositol 3 (PI3)-Akt-mechanistic target of rapamycin (mTOR), PLC- $\gamma$, JAK/signal transducers and activators of transcription (STAT), and Src kinase pathways ${ }^{[11-13]}$. These signaling pathways affect cell growth and proliferation, differentiation, invasion, migration, apoptosis, angiogenesis, cell cycle progression, and immune function ${ }^{[11,14,15]}$. The canonical Wnt/ $\beta$-catenin signaling pathway is initiated when one of its ligands binds to the receptor complex. This causes phosphorylation and activation of the protein dvl-1, which inhibits a destruction complex normally responsible for recruitment, phosphorylation, ubiquitylation, and proteasomal degradation of $\beta$-catenin. Signal activation and sequestration of the destruction complex to the plasma membrane prevents the phosphorylation of $\beta$-catenin, which subsequently accumulates in the cytoplasm, translocates to the nucleus, and activates transcription of target genes ${ }^{[16-19]}$. In human breast cancer, $\beta$-catenin transactivates vimentin, a known EMT marker ${ }^{[20]}$. $\beta$-catenin also forms a complex that binds to the cytoplasmic tail of E-cadherin, connecting it to the actin cytoskeleton ${ }^{[21-24]}$. 
Cross-talk between the canonical Wnt/ $\beta$-catenin and EGFR signaling pathways is evidenced in cancer cells. For example, the EGFR signaling pathway activates the transcription of canonical Wnt $/ \beta$-catenin target genes such as cyclinD1, c-myc, and survivin. In oral and non-small cell lung cancers, there is a link between EGFR mutations and accumulation of $\beta$-catenin within the nucleus ${ }^{[25,26]}$. The EGFR signaling pathway is turned on by Wnt ligands through the Fzd receptor, leading to cleavage of EGF-like ligands ${ }^{[27,28]}$. EGFR signaling is transactivated in breast cancer patients after knockdown of the Wnt negative regulator SFRP1. Increased expression of Wnt1 and decreased expression of APC activates EGFR signaling in breast cancer $^{[28,29]}$. Down-regulation of $\beta$-catenin decreases levels of EGFR, STAT3 and Akt mRNA ${ }^{[30]}$. E-cadherin regulates EGFR localization and activation ${ }^{[31]}$. NKD2 is a negative regulator of Dvl-1, which promotes $\beta$-catenin translocation to the nucleus ${ }^{[32,33]}$. The $\mathrm{N}$-terminal region of NKD2 also contains a moiety capable of binding to precursor TGF- $\alpha$ ( $36 \mathrm{kDa})$, a ligand for the EGFR signaling pathway. This interaction facilitates the escort of precursor TGF- $\alpha$ to the plasma membrane, whereby it is cleaved into mature TGF- $\alpha$ (17 kDa), cleaved into a soluble form $(6 \mathrm{kDa})$, and secreted ${ }^{[29,34]}$.

These previous studies establish a relationship between the EGFR and canonical Wnt/ $\beta$-catenin signaling pathways. They also illustrate the complexity involved in this signaling pathway cross-talk. Hyperactivation of both signaling pathways is a signature of aggressive human breast cancer. NKD2 is involved in a positive feedback loop in the EGFR signaling pathway and is a known inhibitor of the canonical Wnt/ $\beta$-catenin signaling pathway. It is likely that NKD2 acts as a "molecular switch" between these pathways in breast cancer development and/or progression. The exact mechanism for this communication remains elusive. We have established a 3D in vitro ESC-microstrand tumor model by encapsulating ESCs in small-diameter alginate microstrands and co-culturing with metastatic human BCCs. The creation of a 3D in vitro ESCmicrostrand tumor model to probe signaling pathway-related molecules following restoration of signaling pathway function will provide insight into this complex process ${ }^{[8,10]}$. This model restricts metastatic BCC proliferation, survival, metabolism, invasion, migration, and oncogene expression, as summarized in Table $1^{[10]}$. To further understand the underlying mechanism for ESCs' inhibitory effect on BCCs, we hypothesized that ESC-microstrands will inhibit the EGFR and canonical Wnt/ $\beta$-catenin signaling pathways in highly aggressive cancer due to restored signaling pathway regulation. To test this hypothesis, co-cultured BCCs were treated with EGFR and canonical Wnt/ $\beta$-catenin signaling pathway inhibitors. Next, co-cultured BCCs were probed at the molecular level for expression of key molecules related to the EGFR and canonical Wnt/ $\beta$-catenin signaling pathways using quantitative reverse transcription polymerase chain reaction (qRT-PCR) and Western blot analysis. Changes in gene expression would reflect the ability of pluripotent signals from ESC-microstrands to reverse oncogenic signaling pathway hyperactivation and restore signaling pathway regulation in metastatic BCCs.

\section{METHODS}

\section{Cell culture}

Mouse CCE ESCs were purchased from StemCell Technologies (Vancouver, Canada) and cultured in 0.1\% gelatin-coated flasks. The growth medium consisting of DMEM with $4.5 \mathrm{~g} / \mathrm{L} D$-glucose supplemented with $15 \%$ (v/v) FBS, $100 \mathrm{U} / \mathrm{mL}$ penicillin, $100 \mu \mathrm{g} / \mathrm{mL}$ streptomycin, $0.1 \mathrm{mmol} / \mathrm{L}$ MEM non-essential amino acids, $10 \mathrm{ng} / \mathrm{mL}$ murine recombinant LIF (StemCell Technologies, Vancouver, Canada), $0.1 \mathrm{mmol} / \mathrm{L}$ monothioglycerol, $2 \mathrm{mmol} / \mathrm{L} \mathrm{L}$-glutamine, and $1 \mathrm{mmol} / \mathrm{L}$ sodium pyruvate. Cell media was changed every day and cells were passaged every 2 to 3 days. Human MDA-MB-231 and MCF7 BCCs were purchased from ATCC (Manassas, VA). Cells were cultured in growth medium consisting of DMEM supplemented with 15\% (v/v) FBS, $100 \mathrm{U} / \mathrm{mL}$ penicillin, $100 \mu \mathrm{g} / \mathrm{mL}$ streptomycin and $2 \mathrm{mmol} / \mathrm{L} \mathrm{L}$-glutamine. Human 3T3 fibroblasts were obtained from the NIH and cultured in growth medium containing DMEM supplemented with 15\% (v/v) FBS, $100 \mathrm{U} / \mathrm{mL}$ penicillin, and $100 \mu \mathrm{g} / \mathrm{mL}$ streptomycin. All cell lines were maintained at $37^{\circ} \mathrm{C}$ in a humidified atmosphere containing $5 \% \mathrm{CO}_{2}$. 
Table 1. Summarization of inhibitory effects of 3D ESC-microstrands on BCCs ${ }^{[10]}$

\begin{tabular}{lc}
\hline Cancer cell property & Co-cultured BCC \\
\hline Proliferation & \\
WST-1 assay & $\downarrow$ \\
Cell cycle analysis-G2/M population & $\downarrow$ \\
Cell cycle analysis-S population & $\uparrow$ \\
Apoptosis/necrosis & $\uparrow$ \\
Annexin-V FITC propidium iodide assay & $\uparrow$ \\
Cell cycle analysis-SubG1 population & $\uparrow$ \\
Cell metabolism & $\downarrow$ \\
Glycolysis & $\downarrow$ \\
Oxidative phosphorylation & \\
Epithelial-to-mesenchymal transition & $\uparrow$ \\
E-cadherin protein expression & $\downarrow$ \\
Vimentin protein expression & $\downarrow$ \\
Cell migration & $\downarrow$ \\
Invasiveness & $\downarrow$ \\
\hline
\end{tabular}

ESC: embryonic stem cell; BCC: breast cancer cell

\section{Microfluidic synthesis of 3D ESC-microstrands by encapsulating ESCs in alginate hydrogels}

A sodium alginate solution $(1.5 \% \mathrm{w} / \mathrm{v}$ alginate dissolved in $0.9 \% \mathrm{w} / \mathrm{v}$ sodium chloride) containing ESCs suspended at a density of $1 \times 10^{6}$ cells $/ \mathrm{mL}$ was loaded into a $3 \mathrm{~mL}$ syringe, which was placed in a New Era NE-1000 syringe pump (New Era, Farmingdale, NY). A $50 \mathrm{mmol} / \mathrm{L} \mathrm{CaCl}_{2}$ solution was placed in one well of a 24-well plate at a volume of $2 \mathrm{~mL}$. The sodium alginate-ESC mixture in the syringe was pumped into the $\mathrm{CaCl}_{2}$ solution at a constant rate of $0.1 \mathrm{~mL} / \mathrm{min}$. Exposing the divalent cation, $\mathrm{Ca}^{2+}$, to sodium alginate crosslinked the polymer chains. This set-up consistently formed microstrands with an approximate $200 \mu \mathrm{m}$ diameter [Figure $1 \mathrm{~A}$ ]. After microstrand formation, the $\mathrm{CaCl}_{2}$ was carefully removed using $200 \mu \mathrm{L}$ micropipette tips, without disturbing the microstrands, and replaced with ESC maintenance media.

\section{Co-culture of 3D ESC-microstrands with breast cancer cells}

As shown in Figure 1B, ESC-microstrands were co-cultured with 2D BCCs or fibroblasts by cutting them to a specific length, and gently adding them to the well with tweezers. On the same day that ESC-microstrands were formed, MDA-MB-231 BCCs, MCF7 BCCs, and/or 3T3 fibroblasts were seeded at a cell density of $2 \times 10^{4} \mathrm{cells} / \mathrm{mL}$ in their media. After $24 \mathrm{~h}$., BCC or $3 \mathrm{~T} 3$ media was replaced with ESC maintenance media. ESC-microstrands were then measured and cut to an appropriate length based on BCC or 3T3 cell density ( $35.0 \mathrm{~mm}$ for approximate $2 \times 10^{4}$ cells) and added to the wells with BCCs or 3T3 cells in ESC maintenance media. After 24,48 , or $72 \mathrm{~h}, \mathrm{BCCs}$ were analyzed using various biological assays. Controls included non-cocultured BCCs and empty alginate hydrogel microstrands. The non-co-cultured control consisted of BCCs in ESC maintenance media and the empty microstrand control included BCCs in ESC maintenance media co-cultured with empty microstrands.

\section{Cell proliferation assay}

Cell proliferation of MDA-MB-231 BCCs was measured using a Premixed WST-1 Cell Proliferation Reagent (Clontech, Mountain View, CA), per manufacturer's instruction.

\section{Treatment with EGFR and canonical Wnt/ $\beta$-catenin signaling pathway inhibitors}

MDA-MB-231 BCCs were co-cultured with ESC-microstrands for $48 \mathrm{~h}$. and subsequently treated with 5, 10, or $20 \mu \mathrm{mol} / \mathrm{L}$ of either the EGFR inhibitor Erlotinib, the canonical Wnt/ $\beta$-catenin inhibitor PNU74654, or both to determine how sensitive these cells were to both chemotherapeutic inhibitors. Controls included non-co-cultured BCCs and non-drug-treated BCCs. After $48 \mathrm{~h}$, the sensitivity of the BCCs to drug treatment was assessed using a WST-1 cell proliferation assay per manufacturer's instructions. For the drug resistance experiments, cells were treated with chemotherapeutic drugs up to four times for $24 \mathrm{~h}$ each and allowed to recover for either 24 or $48 \mathrm{~h}$ prior to analysis. 
A.

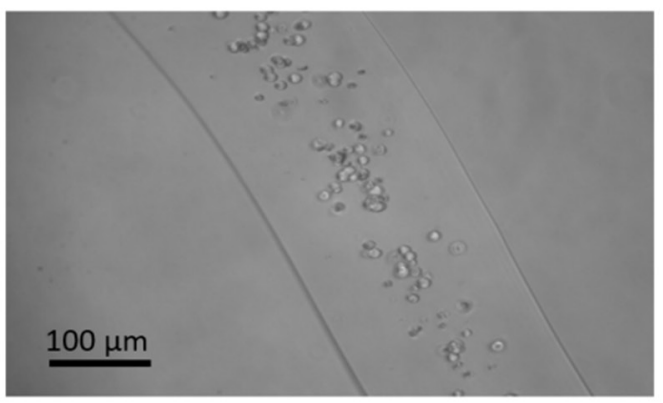

B.

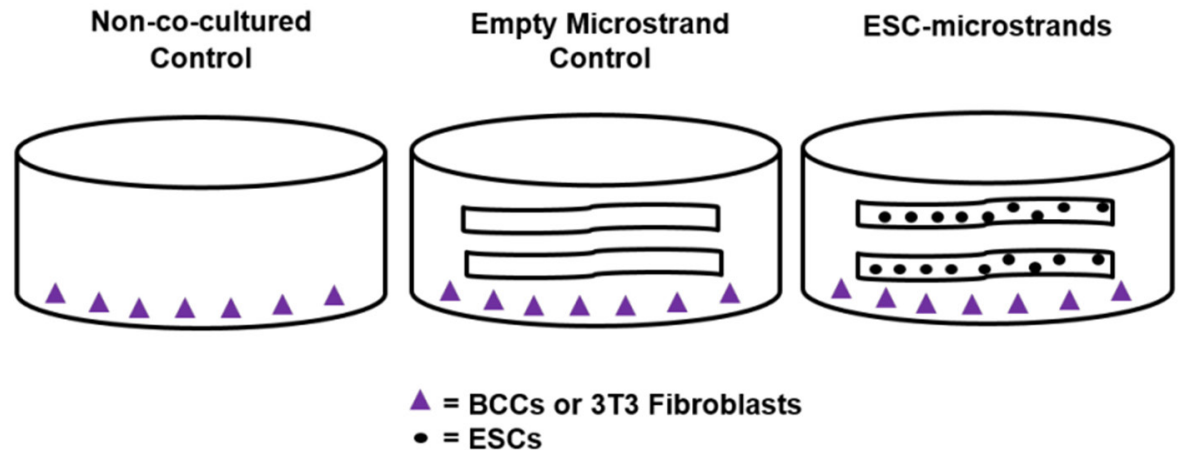

Figure 1. Schematic for co-culture of $3 D$ embryonic stem cell (ESC)-microstrands with human breast cancer cells (BCCs). A: Optical image of mouse ESCs encapsulated in alginate hydrogel microstrands; B: experimental set-up of BCC alone (left), cultured with empty microstrands (middle), and co-cultured with 3D ESC-microstrands (right). No microstrands, empty microstrands, and 3T3 fibroblasts instead of BCCs served as experimental controls

\section{qRT-PCR analysis}

Cells were washed once with $0.5 \mathrm{~mL}$ of ice cold PBS. Total RNA of MDA-MB-231 BCCs was isolated using an RNeasy Mini Kit (Qiagen, Valencia, CA), per manufacturer's instruction. The RNA was of high purity with 260/280 values close to 2.0. Starting with $125 \mathrm{ng} / \mathrm{mL}$ of total RNA, cDNA was synthesized using an Omniscript first-strand cDNA synthesis kit (Invitrogen, Grand Island, NY). qRT-PCR was executed using a StepOnePlus $^{\text {TM }}$ Real Time PCR System (Applied Biosystem, Foster City, CA). The Mastermix contained $1.25 \mu \mathrm{L}$ of the forward and reverse primers [Table 2], 12.5 $\mu \mathrm{L}$ of SYBR ${ }^{\star}$ Green PCR Master Mix (Life Technologies, Carlsbad, CA), and $5 \mu \mathrm{L}$ of Molecular Biology Grade water (Corning, Inc., Corning, NY). Each sample was performed in triplicate and a negative control containing Molecular Biology Grade water instead of cDNA was included in every trial. The $\Delta \Delta \mathrm{Ct}$ method was applied for quantification using $\beta$-actin as an internal control.

\section{Western blot analysis}

BCCs were washed with ice cold PBS and lysed through exposure to $0.2 \mathrm{~mL}$ of ice cold RIPA buffer (Sigma Aldrich) for $20 \mathrm{~min}$ while pipetting up and down. Cell lysates were centrifuged at 12,000 rpm for $20 \mathrm{~min}$ at $4{ }^{\circ} \mathrm{C}$. The cell pellet was discarded, and the concentration of total protein was assessed using a BCA assay, per manufacturer's instructions. The protein samples were boiled for $10 \mathrm{~min}$ and loaded into the wells $(15 \mu \mathrm{g})$ of a NuPage ${ }^{\star}$ Novex $^{\star} 4 \%-12 \%$ Bis-Tris Protein Gel (Thermo Fisher Scientific, Waltham, MA) for separation through electrophoresis ( $100 \mathrm{~V}$ for $2 \mathrm{~h}$ ). The running buffer, $1 \times$ NuPAGE$^{\bullet}$ MOPS SDS (Thermo Fisher Scientific, Waltham, MA), contained $50 \mathrm{mmol} / \mathrm{L}$ MOPS, $50 \mathrm{mmol} / \mathrm{L}$ Tris Base, $0.1 \%$ SDS, and $1 \mathrm{mmol} / \mathrm{L}$ EDTA. Prior to loading, cell lysates were mixed with LDS sample buffer (4:1) (Pierce ${ }^{\mathrm{TM}}$ Chemical, Rockford, IL) containing 0.5 mol/L dithiothreitol (DTT) (10:1) (Invitrogen, Grand Island, NY). 
Table 2. Forward and reverse primer sequences for $\mathrm{QRT}$-PCR

\begin{tabular}{lll}
\hline Target & \multicolumn{1}{c}{ Forward sequence $\left(\mathbf{5}^{\prime} \boldsymbol{\rightarrow} \mathbf{\mathbf { 3 } ^ { \prime } \mathbf { ) }}\right.$} & \multicolumn{1}{c}{ Reverse sequence $\mathbf{( 5}^{\prime} \boldsymbol{\rightarrow} \mathbf{3}^{\prime} \mathbf{)}$} \\
\hline EGFR & CTC CCA GTG CCT GAA TAC ATA AA & CCG TGG TCA TGC TCC AAT AA \\
$\beta$-catenin & GCT CCT TCT CTG AGT GGT AAA G & CAC CTG GTC CTC GTC ATT TAG CTT GTA \\
Vimentin & GAT TCA CTC CCT CTG GTT GAT AC & GGA GTG TCG GTT GTT \\
NKDD2 & AGA TAC ACA TGC CGT ACA CCA C & CGG CAG GTA GTA GCT GAA GG \\
TGF- $\alpha$ & CCC TGC GAA GAC TTG AGA TTT A & GGA GCT TGC AGA GAT GGA TTA G \\
GAPDH & GAT TCC ACC CAT GGC AAA TTC & GTC ATG AGT CCT TCC ACG ATA C \\
$\beta$-actin & AAA GAC CTG TAC GCC AAC ACA GTG CTG TCT & CGT CAT ACT CCT GCT TGC TGA TCC ACA TCT G \\
\hline
\end{tabular}

qRT-PCR: quantitative reverse transcription polymerase chain reaction

Table 3. Antibodies used for western blot analysis

\begin{tabular}{llll}
\hline Target & Species & Company & Dilution/concentration \\
\hline EGFR & Goat & Santa Cruz Biotechnology & $1: 500$ \\
E-cadherin & Rabbit & Santa Cruz Biotechnology & $1: 500$ \\
Vimentin & Mouse & Abcam & $1: 1000$ \\
TGF- $\alpha$ & Rabbit & Abcam & $0.2 \mu \mathrm{g} / \mathrm{mL}$ \\
$\beta$-catenin & Mouse & Santa Cruz Biotechnology & $1 \mu \mathrm{g} / \mathrm{mL}$ \\
NKD2 & Rabbit & Abcam & $1: 500$ \\
$\beta$-actin & Mouse & Santa Cruz Biotechnology & $1: 1000$ \\
GAPDH & Mouse & Life Technologies & $1 \mu \mathrm{g} / \mathrm{mL}$ \\
pERK & Mouse & Santa Cruz Biotechnology & $1: 500$ \\
pEGFR & Goat & Santa Cruz Biotechnology & $1: 500$ \\
\hline
\end{tabular}

RIPA buffer was added to give a final volume of $20 \mu \mathrm{L}$ per well. $\beta$-actin was utilized as a loading control and $10 \mu \mathrm{L}$ of Precision Plus Protein ${ }^{\mathrm{TM}}$ WesternC ${ }^{\mathrm{TM}}$ Standards (BioRad, Hercules, CA) was added to a well as a molecular weight reference. The proteins were wet-transferred onto a nitrocellulose membrane for $1 \mathrm{~h}$ at 100V. The transfer buffer consisted of $1 \times$ Tris-glycine buffer with $20 \%(\mathrm{v} / \mathrm{v})$ methanol. Prior to transfer, the nitrocellulose membrane was incubated for $10 \mathrm{~min}$ in 100\% methanol for activation. Following wet transfer, the nitrocellulose membrane was washed three times in Tris-buffered saline and Tween 20 (TBST) in 15min intervals and incubated for $1 \mathrm{~h}$ at RT in $5 \%(\mathrm{w} / \mathrm{v})$ BSA diluted in TBST. The nitrocellulose membrane was incubated overnight at $4{ }^{\circ} \mathrm{C}$ in a primary antibody [Table 3], which was diluted in TBST. Three 15min washes in TBST were performed, followed by one-hour incubation at RT in a secondary antibody diluted in TBST. Three washes were performed again in TBST and the nitrocellulose membrane was placed in Supersignal $^{\mathrm{TM}}$ West Femto Maximum Sensitivity Substrate (Thermo Fisher Scientific, Waltham, MA) according to manufacturer's instructions. Signal detection was accomplished using a FluorChem E system (Protein Simple, San Jose, CA).

\section{Statistical analysis}

Data analyses were performed using a one-way ANOVA with multiple comparisons. Data were expressed as the mean \pm standard deviation. A value of $P<0.05$ was considered statistically significant. Experiments were repeated 2-3 times.

\section{RESULTS}

\section{ESC-microstrands increase MDA-MB-231 BCC sensitivity to chemotherapeutic drugs}

Highly aggressive MDA-MB-231 BCCs were treated with the chemotherapeutic drugs Erlotinib and PNU 74654, which inhibit the EGFR and canonical Wnt/ $\beta$-catenin signaling pathways, respectively. For both drugs, there was a reduction in BCC viability when treated at a dose of $20 \mu \mathrm{mol} / \mathrm{L}$ with a 24 -h recovery period [Figure 2A].

PNU 74654 decreased metastatic BCC viability more than Erlotinib, with a reduction exceeding $30 \%$. Combining both drugs further diminished cell viability compared to individual treatment. To examine the 
A

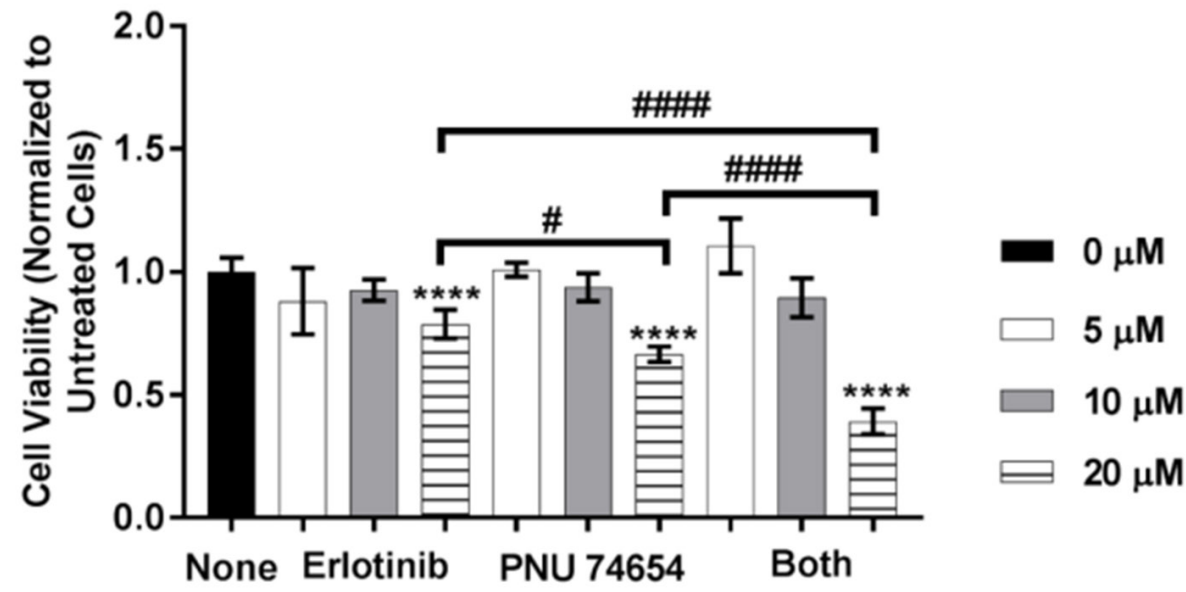

B

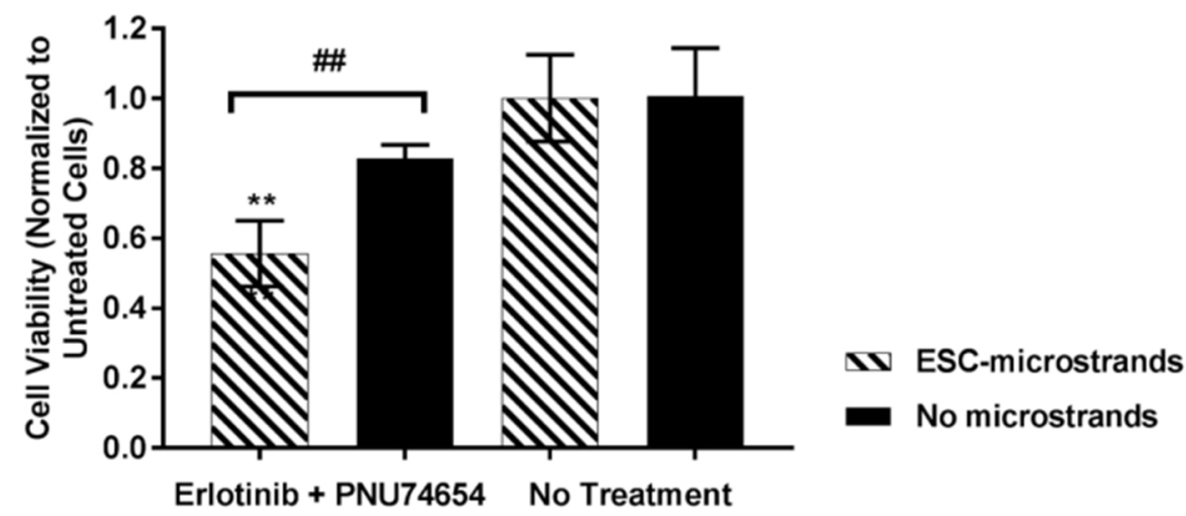

Figure 2. Exposure to embryonic stem cell (ESC)-microstrands overcomes chemotherapeutic drug resistance and reduces metastatic MDA-MB-231 cancer cell survival after drug treatment. A: MDA-MB-231 breast cancer cells (BCCs) were sensitive to the chemotherapeutic drugs Erlotinib and PNU 74654 when treated with $20 \mu \mathrm{mol} / \mathrm{L}$ for $30 \mathrm{~min}$, followed by a 24-h recovery period. Simultaneous treatment with Erlotinib and PNU 74654 resulted in the largest decrease in cell viability suggesting that both pathways play a role in the metastatic phenotype; B: after being co-cultured with ESC-micorstrands, MDA-MB-231 BCCs exhibited significant reduction in cell viability after three cycles of treatment and recovery with both drugs at $20 \mu \mathrm{mol} / \mathrm{L}$ compared to non-co-cultured BCC control.

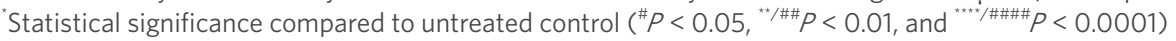

effect of ESC-microstrands on chemotherapeutic drug resistance, cells were treated three times with both chemotherapeutic drugs at a dose of $20 \mu \mathrm{mol} / \mathrm{L}$, and viability was compared to the non-co-cultured BCCs. Three 24-h treatment and 24-h recovery cycles were performed to simulate the drug resistant state caused by multiple chemotherapeutic treatments in vivo. At the end of the treatments, the co-cultured BCCs were more sensitive to the chemotherapeutic drugs compared to the non-co-cultured BCCs [Figure 2B].

\section{Co-culture with ESC-microstrands reverses oncogenic gene expression of MDA-MB-231 BCCs}

To understand the inhibitory effect of exposure to ESC-microstrands on metastatic BCCs, relative mRNA expression levels of EGFR and canonical Wnt/ $\beta$-catenin signaling pathway-related molecules of MDAMB-231 BCCs following co-culture with ESC-microstrands were examined using qRT-PCR. We have previously shown that co-culture with ESC-microstrands increases NKD2 and decreases TGF- $\alpha$ mRNA expression after $48 \mathrm{~h}^{[10]}$. NKD2 is a negative regulator of the canonical Wnt/ $\beta$-catenin signaling pathway and TGF- $\alpha$ is a ligand that activates the EGFR signaling pathway. Similar changes in NKD2 and TGF- $\alpha$ gene expression following co-culture with ESC-microstrands were also observed after $72 \mathrm{~h}$ [Figure 3A].

The differences between BCCs co-cultured with ESC-microstrands and both the empty microstrand and non-co-cultured controls were statistically significant. For both $48 \mathrm{~h}$ (data not shown) and $72 \mathrm{~h}$, there was a 
A

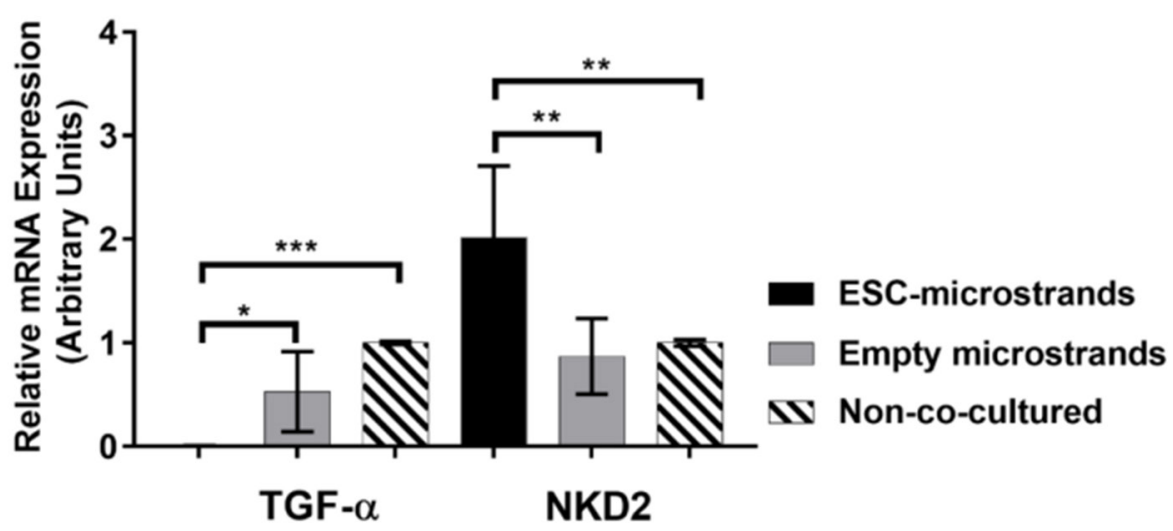

B
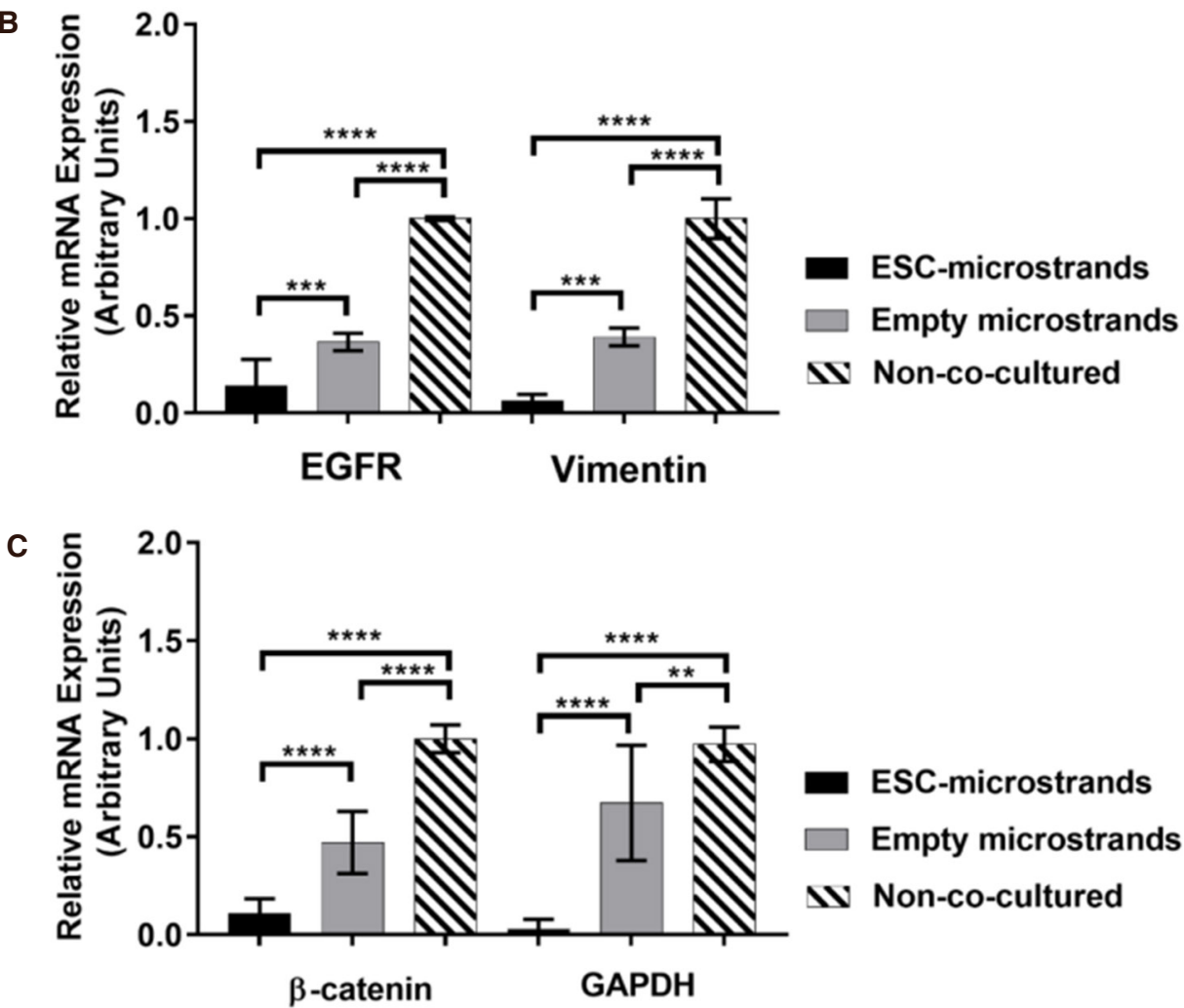

Figure 3. Reversal of gene expression of metastatic MDA-MB-231 breast cancer cells (BCCs) after exposure to embryonic stem cell (ESC)-microstrands at the transcriptional level as revealed by qRT-PCR analysis. A: After $72 \mathrm{~h}$, significantly decreased TGF- $\alpha$ and increased NKD2 gene expression in BCCs co-cultured with ESC-microstrands compared to both empty microstrand and non-co-cultured controls; B: after $72 \mathrm{~h}$, EGFR and vimentin gene expression decreased significantly compared to both controls; C: after $48 \mathrm{~h}, \beta$-catenin and GAPDH gene expression declined in BCCs co-cultured with ESC-microstrands compared to the both controls ( ${ }^{\star \star \star \star} P<0.0001$; ${ }^{\star \star \star} P<0.001$ : $\left.{ }^{\star \star} P<0.01 ;{ }^{*} P<0.05\right)$

decline in both EGFR and vimentin mRNA levels in the BCCs co-cultured with ESC-microstrands [Figure 3B]. There was also a decline in expression in the empty microstrand group for both EGFR and vimentin, but it is not as extreme as for the ESC-microstrand group. Finally, both $\beta$-catenin and GAPDH mRNA levels decreased in the BCCs after co-culture with ESC-microstrands for $48 \mathrm{~h}$ [Figure $3 \mathrm{C}$ ]. This decrease persisted for $\beta$-catenin, but not for GAPDH, after $72 \mathrm{~h}$ (data not shown).

ESC-microstrands reverse EGFR and $\beta$-catenin protein expression in metastatic BCCs

We further examined expression of EGFR, $\beta$-catenin, NKD2, and TGF- $\alpha$ in metastatic MDA-MB-231 BCCs at protein level after $48 \mathrm{~h}$ of co-culture with ESC-microstrands, in comparison with non-invasive 
A

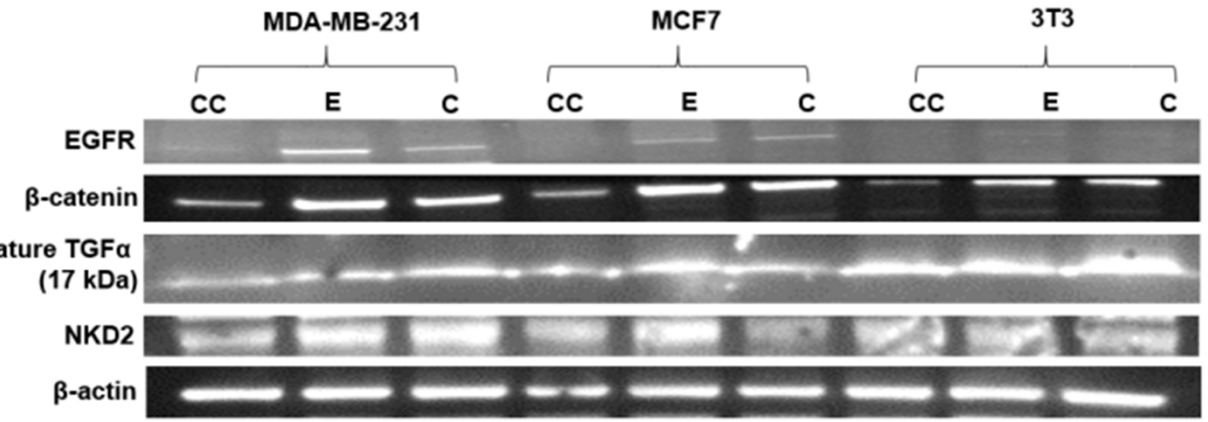

B
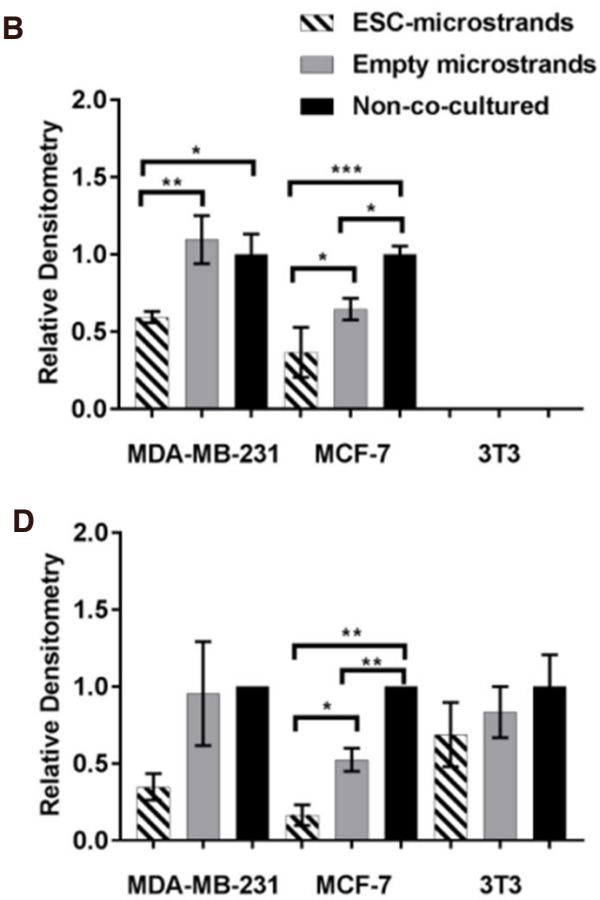

C

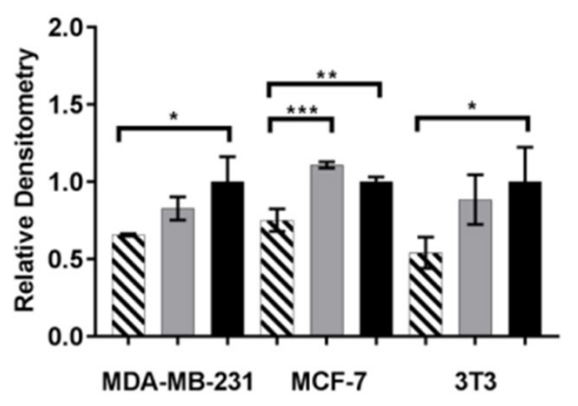

E

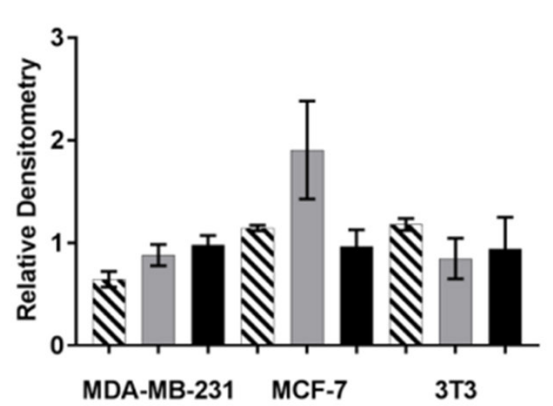

Figure 4. Protein expression of key signaling pathway molecules in metastatic MDA-MB-231 breast cancer cells (BCCs) after co-culture with embryonic stem cell (ESC)-microstrands for $48 \mathrm{~h}$ in comparison to non-aggressive MCF7 BCCs and 3T3 fibroblasts. Western blots show reduced EGFR, $\beta$-catenin, and mature TGF- $\alpha$ protein expression in the co-cultured MDA-MB-231 BCCs (CC: co-cultured with ESCmicrostrands; $E$ : co-cultured with empty microstrands; $C$ : non-co-cultured control) (A); densitometry of protein expression of EGFR (B); $\beta$-catenin (C); mature TGF- $\alpha(D) ;$ NKD2 (E) $\left({ }^{\star \star \star} P<0.001\right.$; ${ }^{\star \star} P<0.01$; and $\left.{ }^{\star} P<0.05\right)$

MCF7 BCCs and 3T3 fibroblasts [Figure 4A]. Western blot analysis of MDA-MB-231 BCCs after $48 \mathrm{~h}$ of coculture with ESC-microstrands revealed a decline in EGFR protein expression compared to both empty microstrands and non-co-cultured controls [Figure 4B]. A similar trend was observed in the MCF7 BCCs, however, the reduction following co-culture with ESC-microstrands was also significantly different than the non-co-cultured control. The $3 \mathrm{~T} 3$ fibroblasts did not express EGFR. There was also a reduction in $\beta$-catenin expression following co-culture with ESC-microstrands for all three cell types that was statistically different than the non-co-cultured control [Figure 4C]. However, only the MCF7 BCCs showed statistical significance when comparing the ESC-microstrands to the empty microstrands. TGF- $\alpha$ expression was decreased for both BCC types following co-culture with ESC-microstrands, but only the MCF7 BCCs showed statistical significance when compared to both controls [Figure $4 \mathrm{D}$ ]. Finally, after $48 \mathrm{~h}, \mathrm{NKD} 2$ protein expression did not significantly change following co-culture with ESC-microstrands or empty microstrands for any cell type [Figure $4 \mathrm{E}]$.

\section{ESC-microstrands restore EGFR and canonical Wnt/ $\beta$-catenin signaling pathway function}

Since co-culture with ESC-microstrands decreased EGFR and $\beta$-catenin expression in MCF7 and MDAMB-231 BCCs following $48 \mathrm{~h}$ of co-culture, ESC-microstrands and media were removed and replaced with 
A

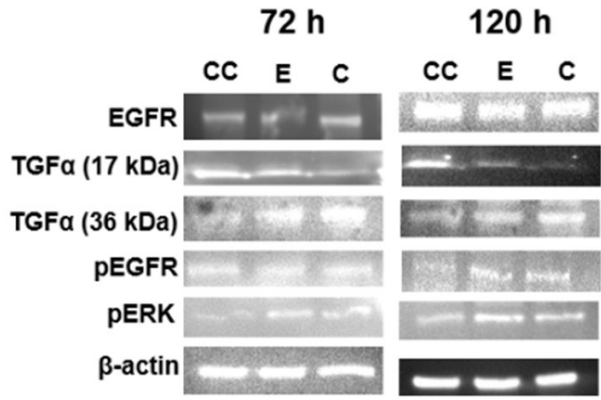

C

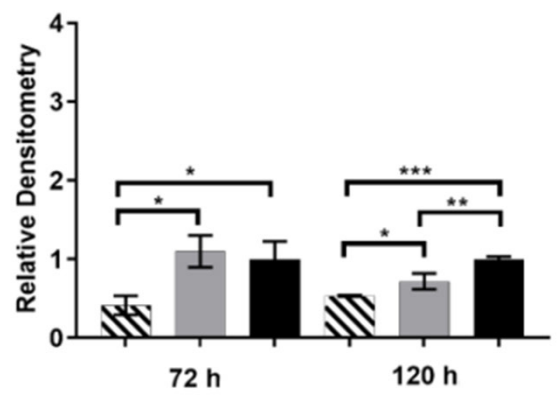

E

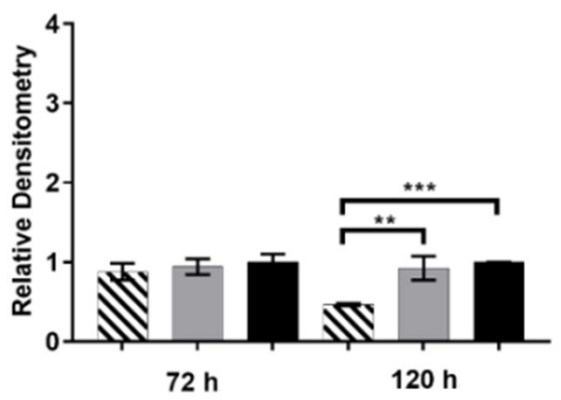

B

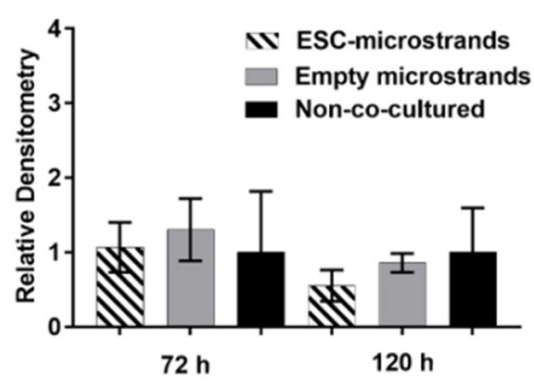

D

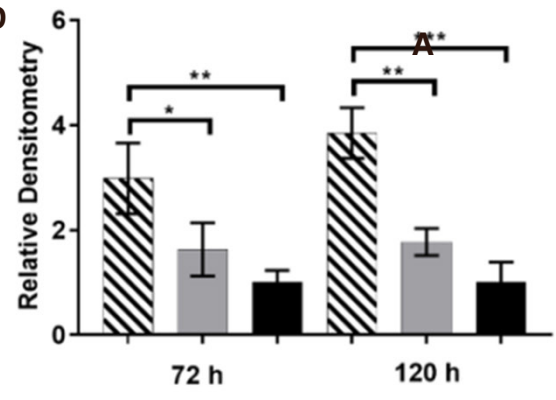

$\mathbf{F}$

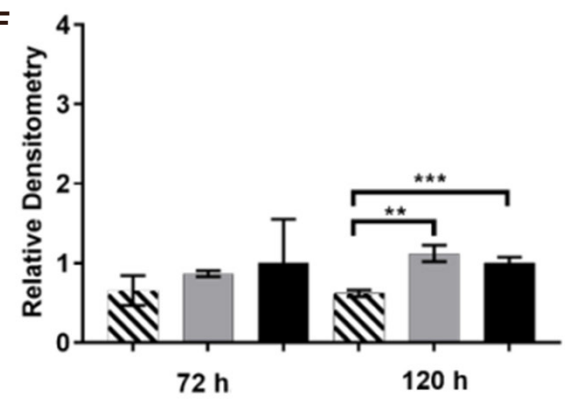

Figure 5. Western blot analysis of long-term protein expression of key EGFR signaling pathway molecules. Metastatic MDA-MB-231 breast cancer cells (BCCs) were co-cultured with embryonic stem cell (ESC)-microstrands for 48 h, followed by removing ESCmicrostrands, replacing BCC media, and analyzing protein expression at $72 \mathrm{~h}$ and $120 \mathrm{~h}$. Western blots for protein expression in metastatic MDA-MB-231 BCCs (CC: co-cultured with ESC-microstrands; E: co-cultured with empty microstrands; C: non-co-cultured

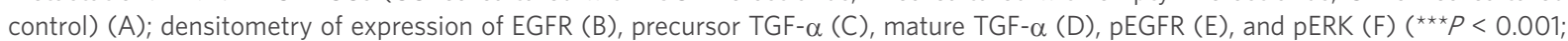
$\left.{ }^{\star \star} P<0.01 ;{ }^{\star} P<0.05\right)$

BCC media to see if there are other long-term signaling pathway-related changes in protein expression in MDA-MB-231 BCCs. The BCCs recovered for either one day or three days, which are denoted as $72 \mathrm{~h}$ and $120 \mathrm{~h}$, respectively. Figure 5A shows the immunoblots for proteins associated with the EGFR signaling pathway. Contrasting to results for $48 \mathrm{~h}$ of co-culture, after $72 \mathrm{~h}$, there was no change in EGFR expression in the MDA-MB-231 BCCs following co-culture with ESC-microstrands [Figure 5B]. Precursor TGF- $\alpha$ levels declined by $72 \mathrm{~h}$ [Figure $5 \mathrm{C}$ ]. There was a statistically significant increase in mature TGF- $\alpha$ expression at the 72-h mark [Figure 5D], which was enhanced by $120 \mathrm{~h}$. There was a decrease after $72 \mathrm{~h}$ in pEGFR expression [Figure 5E]. Finally, there was reduced pERK by $72-\mathrm{h}$ and 120 -h marks [Figure 5F].

Immunoblots for molecules related to the canonical Wnt/ $\beta$-catenin signaling pathway are provided in Figure 6A. Precursor E-cadherin was not present in any of the samples until $120 \mathrm{~h}$, and for that reason, there is no band in the blot for the 72-h point. $\beta$-catenin expression was unchanged following co-culture with ESC-microstrands after $72 \mathrm{~h}$, however, it was significantly reduced by $120 \mathrm{~h}$ compared to both controls [Figure 6B]. At $72 \mathrm{~h}$ and $120 \mathrm{~h}$, there was an upsurge in NKD2 expression following co-culture with ESCmicrostrands that was significant compared to both controls [Figure $6 \mathrm{C}$ ]. By $120 \mathrm{~h}$, there was precursor 
A

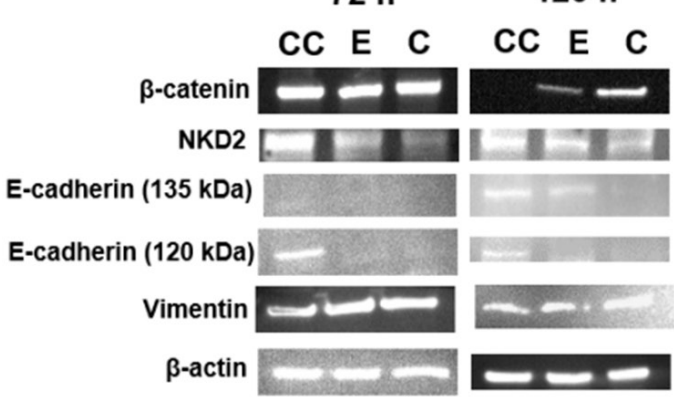

C

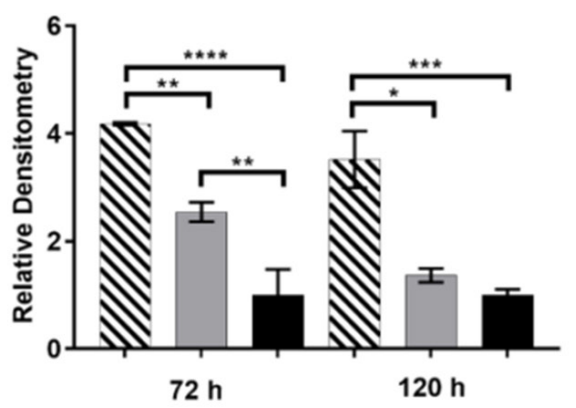

E

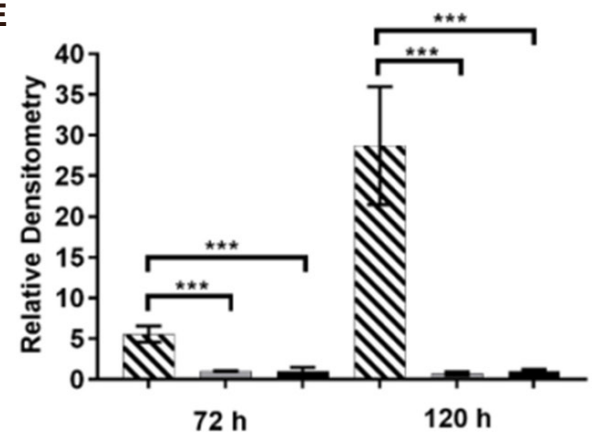

B
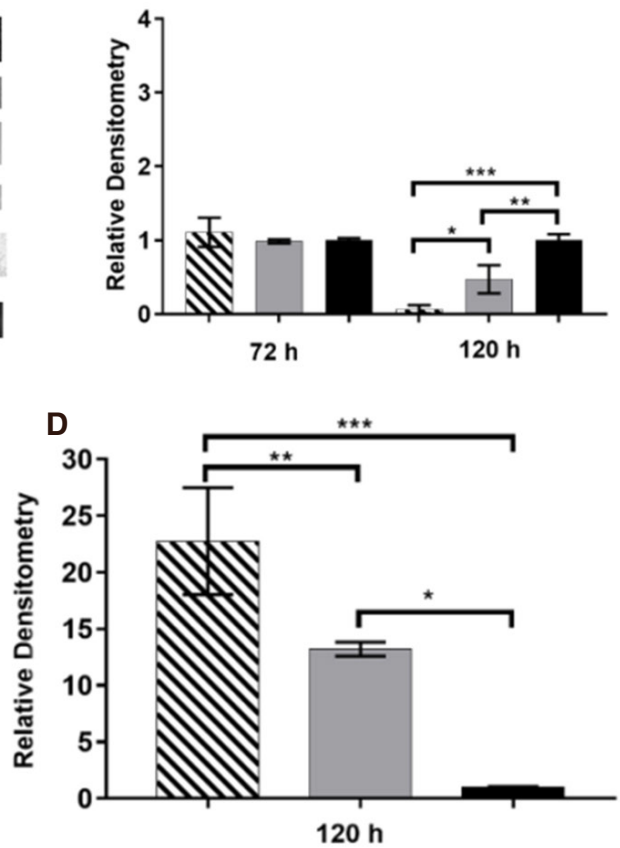

$\mathbf{F}$

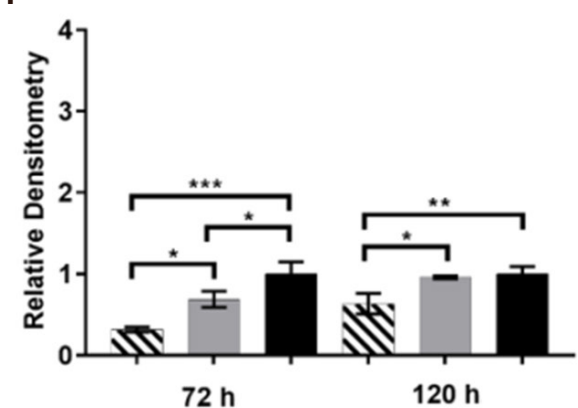

Figure 6. Western blot analysis of long-term protein expression of key canonical Wnt/ $\beta$-catenin signaling pathway molecules. Metastatic MDA-MB-231 breast cancer cells (BCCs) were co-cultured with embryonic stem cell (ESC)-microstrands for 48 h, followed by removing ESC-microstrands, replacing BCC media, and analyzing protein expression at $72 \mathrm{~h}$ and $120 \mathrm{~h}$. Western blots for protein expression in metastatic MDA-MB-231 BCCs (CC: co-cultured with ESC-microstrands; E: co-cultured with empty microstrands; C: non-co-cultured control) (A); densitometry of expression of $\beta$-catenin (B), NKD2 (C), precursor E-cadherin (D), mature E-cadherin (E), and vimentin (F) $\left({ }^{\star \star \star} P<0.001 ;{ }^{\star \star} P<0.01 ;{ }^{\star} P<0.05\right)$

E-cadherin present in the BCCs co-cultured with ESC-microstrands, and it was extremely elevated [Figure 6D]. Mature E-cadherin was expressed in the BCCs co-cultured with ESC-microstrands, but not in the nonco-cultured controls at $72 \mathrm{~h}$. and $120 \mathrm{~h}$ [Figure 6E]. There was some expression in the empty microstrand control at $72 \mathrm{~h}$, however, it was much less. Our previous work demonstrated that co-culture with ESCmicrostrands decreases vimentin protein expression after $48 \mathrm{~h}^{[10]}$. At $72 \mathrm{~h}$ and $120 \mathrm{~h}$, vimentin protein expression was diminished in MDA-MB-231 BCCs co-cultured with ESC-microstrands [Figure 6F].

\section{DISCUSSION}

This work has demonstrated the utility of a bioengineered 3D ESC microenvironment (so-called ESCmicrostrands) for the study of cross-talk of signaling pathways in cancer cells. It reveals that inhibitory effects of the ESC microenvironment on triple negative, metastatic MDA-MB-231 BCCs is attributable to restoration of EGFR and canonical Wnt/ $\beta$-catenin signaling pathway regulation. Simultaneous treatment of 


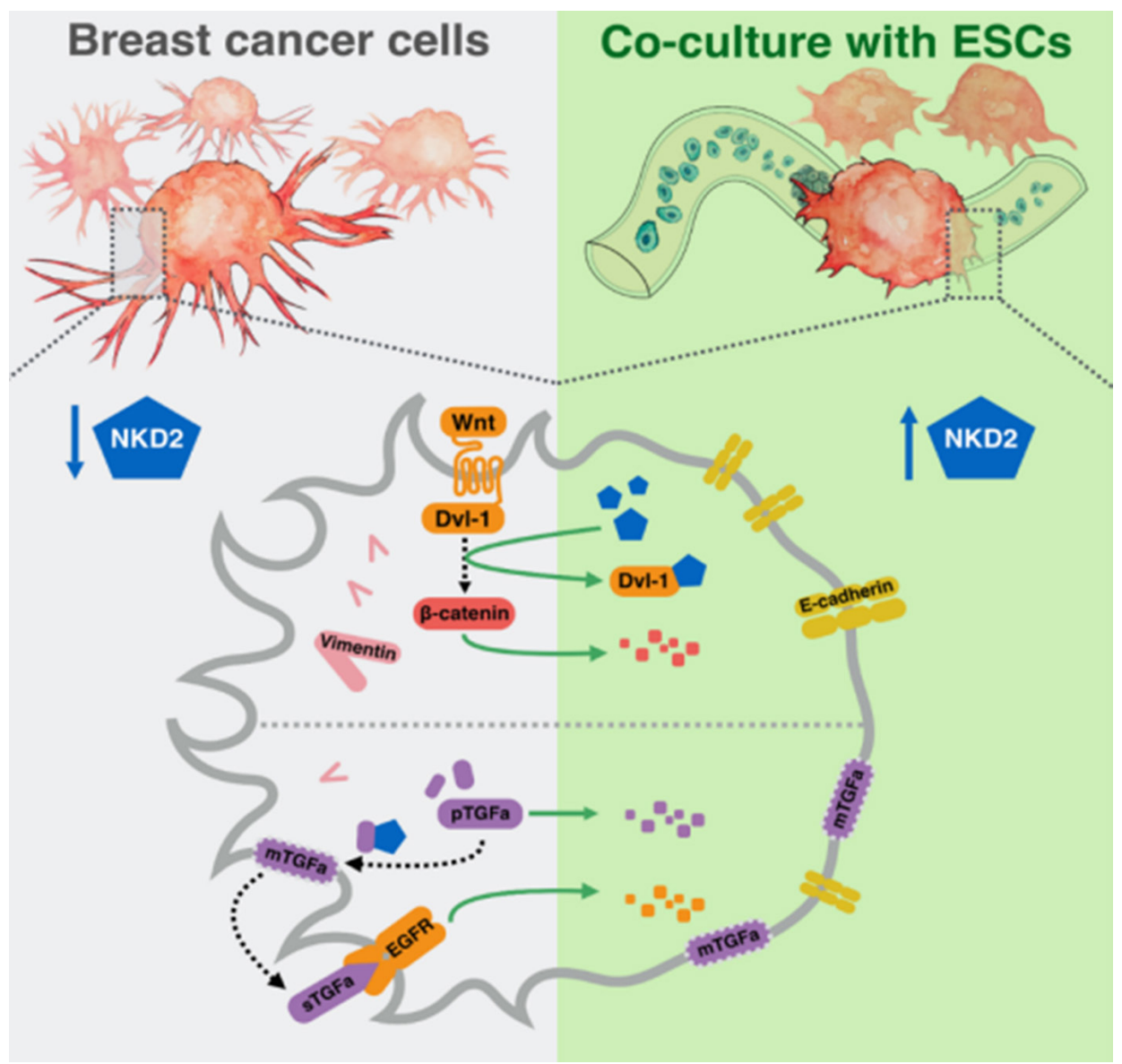

Figure 7. Schematic representation of the effects of co-culture with embryonic stem cell (ESC)-microstrands on expression of key signaling pathway molecules in MDA-MB-231 breast cancer cells (BCCs). Left Panel: BCC alone; Right Panel: co-cultured breast cancer cells with ESC-microstrands. Changes in protein and mRNA expression after co-culture with ESC-microstrands indicated inhibition of the canonical Wnt/ $\beta$-catenin (above the dash line) and EGFR (below the dash line) signaling pathways. Co-culture with ESC-microstrands causes NKD2 up-regulation at both the mRNA and protein levels, and this coincides with dual signaling pathway inhibition. It suggested restored ability of NKD2 to inhibit the canonical Wnt/ $\beta$-catenin signaling pathway and reduced ability to promote the EGFR signaling pathway following co-culture

metastatic BCCs with EGFR and canonical Wnt/ $\beta$-catenin signaling inhibitors suppresses growth more than individual treatment, suggesting that both pathways play a role in the restriction of metastatic phenotype.

The microenvironments of ESCs play a fundamental role in providing cells with appropriate signaling to induce cell proliferation, differentiation, or death. ESCs secrete soluble factors or exosomes that could reprogram malignant cancer cells to benign phenotype and suppress tumorigenesis ${ }^{[35-39]}$. To recapitulate the native stem cell niche, researchers have exploited several bioengineering methods. Researchers have demonstrated that human ESC pluripotency is maintained when the ESCs are cultured in a 3D hyaluronic $\operatorname{acid}^{[40]}$, alginate ${ }^{[41,42]}$, or chitosan scaffold ${ }^{[43]}$. Specifically, our lab has reported that mouse ESCs encapsulated inside aqueous alginate hydrogel microsbeads remain pluripotent and restrict rat breast cancer cell proliferation and migration ${ }^{[8]}$. Our previous work has also established that ESCs encapsulated in alginate microstrands exhibited biological effects on cell behavior of BCCs after co-culture with these ESCmicrostrands, restricting highly aggressive human breast cancer proliferation, survival, invasion, migration, EMT, and metabolic activity ${ }^{[10]}$ as summarized in Table 1 . This study aims to further probe whether this restriction is due to restored signaling pathway function, specifically related to the canonical Wnt/ $\beta$-catenin and EGFR signaling pathways, which are hyperactivated in human breast cancer. 
Deregulation of canonical Wnt//-catenin and EGFR signaling is implicated in various forms of tumorigenesis causing colorectal, lung, breast, ovarian, prostate, liver, and brain cancers ${ }^{[12,44]}$. For the canonical Wnt/ $/$-catenin signaling pathway, cancer also arises from overexpression of Wnt ligand genes, DNA hypermethylation of negative regulators such as 16 and E-cadherin, and overexpression of R-spondins that enhance Wnt ligand function ${ }^{[23,44}$. In BCC lines and primary tumors, Wnt ligands and Fzd receptors are expressed, and $\beta$-catenin is often localized within the nucleus ${ }^{[44]}$. Inhibiting EGFR in cancer cells either directly or with cDNA transfections in vitro and in vivo causes a decrease in proliferation ${ }^{[45]}$. Signaling pathways downstream of the EGFR are deregulated through EGFR mutations, constitutive activation, autocrine/paracrine signaling loops, enhanced ligand production, up- or down-regulation of signaling mediators, and prolonged interactions of EGFR with ErbB2 that either increase EGFR expression, activate EGFR, or prevent its deactivation ${ }^{[14,46]}$. Activation of Rho GTPases downstream of EGFR signaling reduces E-cadherin expression and actin reorganization ${ }^{[4]}$. Certain tumors contain mutations that delete the extracellular binding domain of the EGFR, which constitutively activates the receptor. In glioblastoma, there is frequently an in-frame deletion of exon 2-7 of the EGFR. Ligand-independent activation of the EGFR is caused by overexpression of urokinasetype plasminogen activator receptor and its association with the integrin $\alpha 5 \beta 1^{[11,29,47]}$. Prolonged interaction of ErbB2 with EGFR fosters breast CSC self-renewal through activation of the PI3K/Akt signaling cascade. Increased cellular stress and radiation have been shown to down-regulate phosphatases responsible for the EGFR signal abrogation ${ }^{[48]}$. Downstream of the EGFR signaling pathway, the PI3K/Akt/mTOR pathway activates protein kinase B through loss of PTEN, a tumor suppressor and negative regulator of PI3K/Akt signaling. The result is stabilization of $\beta$-catenin through phosphorylation and inactivation of GSK3. As demonstrated by the previous examples, deregulated canonical Wnt/ $\beta$-catenin and EGFR signaling play an enormous role in many types of aggressive cancer, which highlights the importance of understanding their contribution to aggressive breast cancer progression. As such, our first aim was to examine whether exposure of aggressive MDA-MB-231 BCCs to ESC-microstrands increases sensitivity to chemotherapeutic drugs known to specifically target these two pathways.

Highly aggressive MDA-MB-231 BCCs were treated with the chemotherapeutic drugs Erlotinib and PNU74654. Erlotinib specifically targets the EGFR signaling pathway by binding to the ATP-binding site of the EGFR and preventing phosphorylation by its tyrosine kinase. PNU 74654 targets the canonical Wnt/ $\beta$-catenin signaling pathway by preventing the interaction of $\beta$-catenin with the transcription factor T-cell factor/lymphoid enhancer factor. The canonical Wnt/ $\beta$-catenin signaling pathway may play a larger role in MDA-MB-231 BCC aggressiveness as these cells were more sensitive to PNU74654. However, both signaling pathways are involved in the aggressive phenotype because combining both drugs significantly increases sensitivity. Co-culturing the MDA-MB-231 BCCs with ESC-microstrands prior to dual chemotherapeutic drug treatment coupled with the addition of multiple treatment and recovery periods, demonstrated that coculture with ESC-microstrands increases BCC sensitivity to chemotherapeutic drugs.

Co-culture with ESC-microstrands reduced GAPDH mRNA expression. GAPDH is an enzyme responsible for catalyzing the sixth step of glycolysis. The original intention was to employ GAPDH as a housekeeping gene for this study, though recent works have confirmed GAPDH up-regulation in human breast cancer. A subsequent study by Maltseva et al ${ }^{[49]}$ identified five reliable housekeeping genes in human breast cancer and $\beta$-actin, which was used in this study, was one of the top choices. In our model, GAPDH mRNA expression was decreased in the co-cultured MDA-MB-231 cells, which may explain their decreased glycolytic rate ${ }^{[10]}$. The PI3/Akt pathway lies downstream of the EGFR signaling pathway. GAPDH stabilizes activated Akt allowing oncogenic cells to circumvent caspase-independent cell death. Interestingly, Akt kinase is one of the main contributors to the Warburg effect and Akt also prevents the nuclear accumulation of GAPDH necessary for caspase-dependent cell death ${ }^{[50]}$.

In this work, inhibition of the EGFR signaling pathway following co-culture is demonstrated through reduced EGFR and TGF- $\alpha$ mRNA expression, increased mature TGF- $\alpha$ protein expression, and decreased 
precursor TGF- $\alpha$, pEGFR, and pERK protein expression. The reduction in EGFR protein levels in the coculture after $48 \mathrm{~h}$. is not sustained in the long-term experiment suggesting that EGFR signaling pathway inhibition in the co-culture is not entirely attributable to modulation of EGFR availability. Both soluble $(6 \mathrm{kDa})$ and precursor $(36 \mathrm{kDa}) \mathrm{TGF}-\alpha$ protein levels are elevated in triple negative human breast cancer because cleavage of the precursor form is prevented and cleavage of the mature form is augmented ${ }^{[51]}$. Possible explanations for the decrease in precursor TGF- $\alpha$ expression include (1) prevention of NKD2 from either interacting with precursor TGF- $\alpha$ and/or transporting it to the plasma membrane triggering its degradation; (2) increased cleavage of precursor TGF- $\alpha$ into mature TGF- $\alpha$ within the plasma membrane; and (3) decreased precursor TGF- $\alpha$ production caused by reduced TGF- $\alpha$ mRNA expression. The increase in NKD2 expression coinciding with decreased precursor TGF- $\alpha$ expression suggests that precursor TGF- $\alpha$ is being prevented from interacting with NKD2 and this is triggering its degradation. This would imply that decreased cleavage of mature TGF- $\alpha$ into its soluble form is the major contributor to the augmented mature TGF- $\alpha$ expression, as opposed to increased cleavage of precursor TGF- $\alpha$. The EGFR signaling pathway utilizes phosphorylation cascades to activate downstream molecules that affect cell behavior. Suppression of pEGFR and pERK protein expression after $120 \mathrm{~h}$ indicates that EGFR signaling pathway activation is being suppressed in the co-cultured BCCs. Taken together, the changes in relative mRNA and protein expression in the co-cultured BCCs are extremely promising as they suggest that co-culture is altering the BCCs at both transcriptional and translational levels, indicating that this model can be applied to study the mechanism(s) for signaling pathway inhibition and highly aggressive BCC restriction.

The canonical Wnt/ $\beta$-catenin signaling pathway is hyperactivated in human breast cancer, and this leads to increased $\beta$-catenin expression. In this work, exposing MDA-MB-231 BCCs to ESC-microstrands decreases $\beta$-catenin mRNA and protein expression. The decline in $\beta$-catenin protein levels in western blot analysis signifies its increased ubiquitylation and degradation leading to decreased canonical Wnt/ $\beta$-catenin signaling pathway activation. Three other major signs of canonical Wnt/ $\beta$-catenin inhibition in BCCs co-cultured with ESC-microstrands are increased E-cadherin protein levels, augmented NKD2 mRNA and protein expression, and decreased vimentin mRNA and protein levels. E-cadherin is synthesized as a $135 \mathrm{kDa}$ precursor that undergoes cleavage to its mature $120 \mathrm{kDa}$ form ${ }^{[52]}$. $\beta$-catenin is responsible for anchoring mature E-cadherin to the plasma membrane, and this interaction may contribute to the comparable $\beta$-catenin protein levels in the co-culture and controls after $72 \mathrm{~h}$ coinciding with the extreme up-regulation of mature E-cadherin in the co-cultured BCCs. Co-culture may directly prevent cytoplasmic $\beta$-catenin from translocating to the nucleus. The belief that $\beta$-catenin translocation to the nucleus involves more than its cytoplasmic concentration has gained steam, for example, Fang et al. ${ }^{[53]}$ assert that Akt, which is downstream of EGFR signaling pathway, promotes $\beta$-catenin nuclear translocation through phosphorylation. One possibility is that co-culture leads to decreased activated Akt, which is allowing $\beta$-catenin that has accumulated in the cytoplasm to be used for cell-cell adhesion. After $48 \mathrm{~h}$, there are no detectable levels of mature or precursor E-cadherin in the MDAMB-231 BCCs but there is mature E-cadherin expression in the MCF7 BCCs (data not shown). Interestingly, after restoring the BCC media to demonstrate the long-term effect of co-culture, there is mature and precursor E-cadherin present at the 72- and 120-h marks, respectively. NKD2 is a tumor suppressor that has a very short half-life of approximately sixty minutes and is hypermethylated in human breast cancer ${ }^{[33]}$. The increase in NKD2 mRNA expression in the co-culture denotes a reversal of its methylation status and its increased protein expression suggests an active role in dvl-1 inhibition. Finally, the decreases in vimentin protein and mRNA expression levels in co-cultured BCCs are another sign of inhibition of this pathway because vimentin is transactivated by this pathway.

Our results showed that ESC-microstrands induced changes in gene expression of key regulators at both the mRNA and protein level in MDA-MB-231 BCCs that signified a reversal of the hyperactivated status of EGFR and canonical Wnt/ $\beta$-catenin signaling pathways and restored signaling pathway regulation present in normal non-tumorigenic cells. Specifically, decreased EGFR, pEGFR, pERK, and precursor TGF- $\alpha$ 
coupled with augmented mature TGF- $\alpha$ expression indicated that the EGFR signaling pathway was being suppressed, whilst decreased vimentin and $\beta$-catenin expression coinciding with increased precursor and mature E-cadherin levels supported the notion of canonical Wnt/ $\beta$-catenin signaling pathway suppression. Importantly, these changes corresponded with an extreme up-regulation of NKD2 at both the mRNA and protein levels [Figure 7]. A possible explanation for this phenomenon is that co-culture with ESCmicrostrands restores NKD2 expression in metastatic MDA-MB-231 BCCs, which enables it to inhibit the canonical Wnt/ $\beta$ catenin signaling pathway, but that NKD2 is also prevented from transporting precursor TGF- $\alpha$ to the membrane for activation of the EGFR signaling pathway.

Altogether, we have demonstrated that exposure of triple negative BCCs to a bioengineered 3D ESC microenvironment restricts their tumorigenic, invasive, and metastatic features owing to restoration of EGFR and canonical Wnt/ $\beta$-catenin signaling pathway regulation. In particular, NKD2 could act as a "molecular switch" between these pathways in BCCs. Co-culture with ESC-microstrands has up-regulated $\mathrm{NKD} 2$ in triple negative, metastatic BCCs both at mRNA and protein levels. The exact role of NKD2 in this metastatic phenotype reversal will be the focus of subsequent studies. Exposure of MDA-MB-231 BCCs to ESC-microstrands may prevent NKD2 myristoylation allowing it to solely interact with Dvl-1 and thwarting precursor TGF- $\alpha$ transport to the plasma membrane causing its increased degradation. Future work will elucidate the mechanism leading to NKD2 preference for either EGFR or canonical Wnt/ $\beta$-catenin signaling pathway interaction allowing for the targeting of NKD2 to treat triple negative breast cancer. This work is important because it establishes that the bioengineered 3D ESC model can not only restrict triple negative breast cancer survival and metastatic potential, but can also be applied to determine the mechanism for this restriction and identify therapeutic targets to reverse metastatic disease. This is the first example of exploring the role of NKD2 in aggressive breast cancer as all other studies in literature were performed in colon cancer. In the future, we may test whether using ESC-microstrand-conditioned media could achieve the same level of restriction of cancer metastasis. Additionally, the use of a panel of triple negative metastasis breast cancer cells (e.g., MDA-MB-157, MDA-MB-468) will further validate our findings and confirm the utility of the 3D ESC model system for understanding cancer metastasis.

\section{DECLARATIONS}

\section{Authors' contributions}

Made substantial contributions to conception and design of the study and performed data analysis and interpretation: Mooney B and Xie Y

Performed data acquisition and provided technical and material support: Mooney B

Created Figure 7 and revised the paper: Tian Y

Assisted in drug resistance experiments and revised the paper: Rousseau E

\section{Availability of data and materials}

Not applicable.

\section{Financial support and sponsorship}

This work was supported by National Science Foundation (CBET0846270).

\section{Conflicts of interest}

All authors declared that there are no conflicts of interest.

\section{Ethical approval and consent to participate}

Not applicable.

\section{Consent for publication}

Not applicable. 


\section{Copyright}

(c) The Author(s) 2019.

\section{REFERENCES}

1. Lebert JM, Lester R, Powell E, Seal M, McCarthy J. Advances in the systemic treatment of triple-negative breast cancer. 2018 2018;25:9.

2. Abbott DE, Bailey CM, Postovit LM, Seftor EA, Margaryan N, et al. The epigenetic influence of tumor and embryonic microenvironments: how different are they? Cancer Microenvironment 2008;1:13-21.

3. Quail DF, Siegers GM, Jewer M, Postovit LM. Nodal signalling in embryogenesis and tumourigenesis. Int J Biochem Cell Biol 2013;45:885-98.

4. Mooney BM, Raof NA, Li Y, Xie Y. Convergent mechanisms in pluripotent stem cells and cancer: implications for stem cell engineering. Biotechnol J 2013;8:408-19.

5. Dong W, Qiu C, Shen H, Liu Q, Du J. Antitumor effect of embryonic stem cells in a non-small cell lung cancer model: antitumor factors and immune responses. Int J Med Sci 2013;10:1314-20.

6. Zhang Z, Chen X, Chang X, Ye X, Li Y, et al. Human embryonic stem cells--a potential vaccine for ovarian cancer. Asian Pac J Cancer Prev 2012;13:4295-300

7. Tzukerman M, Rosenberg T, Reiter I, Ben-Eliezer S, Denkberg G, et al. The influence of a human embryonic stem cell-derived microenvironment on targeting of human solid tumor xenografts. Cancer Res 2006;66:3792-801.

8. Abdul Raof N, Mooney BM, Xie Y. Bioengineering embryonic stem cell microenvironments for the study of breast cancer. Int J Mol Sci 2011;12:7662-91.

9. Raof N, Raja W, Castracane J, Xie Y. Bioengineering embryonic stem cell microenvironments for exploring inhibitory effects on metastatic breast cancer cells. Biomaterials 2011;32:4130-9.

10. Mooney B, Abdul-Raof N, Tian YI, Xie Y. Restriction of cancer metastatic potential using embryonic stem cells encapsulated in alginate hydrogel microstrands. ACS Biomater Sci Eng 2017;3:1769-79.

11. Scaltriti M, Baselga J. The epidermal growth factor receptor pathway: a model for targeted therapy. Clin Cancer Res 2006;12:5268-72.

12. Sheeba CJ, Marslin G, Revina AM, Franklin G. Signaling pathways influencing tumor microenvironment and their exploitation for targeted drug delivery. Nanotechnol Rev 2013; doi: 10.1515/ntrev-2013-0032.

13. Merla A, Goel S. Novel drugs targeting the epidermal growth factor receptor and its downstream pathways in the treatment of colorectal cancer: a systematic review. Chemother Res Pract 2012;2012:11.

14. Lemmon MA, Schlessinger J. Cell signaling by receptor tyrosine kinases. Cell 2010;141:1117-34.

15. Lu Y, Brush J, Stewart TA. NSP1 defines a novel family of adaptor proteins linking integrin and tyrosine kinase receptors to the c-Jun N-terminal Kinase/Stress-activated protein kinase signaling pathway. J Biol Chem 1999;274:10047-52.

16. Ahmad A. Pathways to breast cancer recurrence. ISRN Oncol 2013;2013:16.

17. Clevers H. Wnt/ $\beta$-catenin signaling in development and disease. Cell 2006;127:469-80.

18. Clevers H, Nusse R. Wnt/ $\beta$-catenin signaling and disease. Cell 2012;149:1192-205.

19. Green JL, La J, Yum KW, Desai P, Rodewald LW, et al. Paracrine Wnt signaling both promotes and inhibits human breast tumor growth. Proc Natl Acad Sci U S A 2013;110:6991-6.

20. Gilles C, Polette M, Mestdagt M, Nawrocki-Raby B, Ruggeri P, et al. Transactivation of vimentin by $\beta$-catenin in human breast cancer cells. Cancer Res 2003;63:2658-64.

21. Bremm A, Walch A, Fuchs M, Mages J, Duyster J, et al. Enhanced activation of epidermal growth factor receptor caused by tumor-derived E-cadherin mutations. Cancer Res 2008;68:707-14.

22. Lu Z, Ghosh S, Wang Z, Hunter T. Downregulation of caveolin-1 function by EGF leads to the loss of E-cadherin, increased transcriptional activity of $\beta$-catenin, and enhanced tumor cell invasion. Cancer Cell 2003;4:499-515.

23. Nejak-Bowen KN, Monga SPS. Beta-catenin signaling, liver regeneration and hepatocellular cancer: sorting the good from the bad. Semin Cancer Biol 2011;21:44-58.

24. Wilding J, Vousden KH, Soutter WP, McCrea PD, Del Buono R, et al. E-Cadherin transfection down-regulates the epidermal growth factor receptor and reverses the invasive phenotype of human papilloma virus-transfected keratinocytes. Cancer Res 1996;56:5285-92.

25. Lee EYHP, Muller WJ. Oncogenes and tumor suppressor genes. Cold Spring Harb Perspect Biol 2010;2:a003236.

26. Thiery JP, Sleeman JP. Complex networks orchestrate epithelial-mesenchymal transitions. Nat Rev Mol Cell Biol 2006;7:131.

27. Normanno N, De Luca A, Bianco C, Strizzi L, Mancino M, et al. Epidermal growth factor receptor (EGFR) signaling in cancer. Gene 2006;366:2-16.

28. Schlange T, Matsuda Y, Lienhard S, Huber A, Hynes NE. Autocrine WNT signaling contributes to breast cancer cell proliferation via the canonical WNT pathway and EGFR transactivation. Breast Cancer Res 2007;9:R63.

29. Hu T, Li C. Convergence between Wnt- $\beta$-catenin and EGFR signaling in cancer. Molecular Cancer 2010;9:236.

30. Yue X, Lan F, Yang W, Yang Y, Han L, et al. Interruption of $\beta$-catenin suppresses the EGFR pathway by blocking multiple oncogenic targets in human glioma cells. Brain Res 2010;1366:27-37.

31. Rübsam M, Mertz AF, Kubo A, Marg S, Jüngst C, et al. E-cadherin integrates mechanotransduction and EGFR signaling to control junctional tissue polarization and tight junction positioning. Nat Commun 2017;8:1250.

32. Dong Y, Cao B, Zhang M, Han W, Herman JG, et al. Epigenetic silencing of NKD2, a major component of wnt signaling, promotes breast cancer growth. Oncotarget 2015;6:22126-38.

33. Zhao S, Kurenbekova L, Gao Y, Roos A, Creighton CJ, et al. NKD2, a negative regulator of Wnt signaling, suppresses tumor growth and metastasis in osteosarcoma. Oncogene 2015;34:5069.

34. Li C, Franklin JL, Graves-Deal R, Jerome WG, Cao Z, et al. Myristoylated Naked2 escorts transforming growth factor $\alpha$ to the basolateral 
plasma membrane of polarized epithelial cells. Proc Natl Acad Sci U S A 2004;101:5571-6.

35. Zhou S, Abdouh M, Arena V, Arena M, Arena GO. Reprogramming malignant cancer cells toward a benign phenotype following exposure to human embryonic stem cell microenvironment. PLoS One 2017;12:e0169899.

36. Postovit LM, Margaryan NV, Seftor EA, Kirschmann DA, Lipavsky A, et al. Human embryonic stem cell microenvironment suppresses the tumorigenic phenotype of aggressive cancer cells. Proc Natl Acad Sci U S A 2008;105:4329-34.

37. He N, Feng G, Li Y, Xu Y, Xie X, et al. Embryonic stem cell preconditioned microenvironment suppresses tumorigenic properties in breast cancer. Stem Cell Res Ther 2016;7:95.

38. Dong W, Qiu C, Shen H, Liu Q, Du J. Antitumor effect of embryonic stem cells in a non-small cell lung cancer model: antitumor factors and immune responses. Int J Med Sci 2013;10:1314-20.

39. Giuffrida D, Rogers IM, Nagy A, Calogero AE, Brown TJ, et al. Human embryonic stem cells secrete soluble factors that inhibit cancer cell growth. Cell Prolif 2009;42:788-98.

40. Gerecht S, Burdick JA, Ferreira LS, Townsend SA, Langer R, et al. Hyaluronic acid hydrogel for controlled self-renewal and differentiation of human embryonic stem cells. Proc Natl Acad Sci 2007;104:11298-303.

41. Siti-Ismail N, Bishop AE, Polak JM, Mantalaris A. The benefit of human embryonic stem cell encapsulation for prolonged feeder-free maintenance. Biomaterials 2008;29:3946-52.

42. Wang W, Liu X, Xie Y, Zhang Ha, Yu W, et al. Microencapsulation using natural polysaccharides for drug delivery and cell implantation. J Mater Chem 2006;16:3252-67.

43. Li Z, Leung M, Hopper R, Ellenbogen R, Zhang M. Feeder-free self-renewal of human embryonic stem cells in 3D porous natural polymer scaffolds. Biomaterials 2010;31:404-12.

44. Watson AL, Rahrmann EP, Moriarity BS, Choi K, Conboy CB, et al. Canonical Wnt/ $\beta$-catenin signaling drives human schwann cell transformation, progression, and tumor maintenance. Cancer Discovery 2013;3:674-89.

45. Hazan RB, Norton L. The epidermal growth factor receptor modulates the Interaction of E-cadherin with the actin cytoskeleton. J Biol Chem 1998;273:9078-84.

46. Mangelberger D, Kern D, Loipetzberger A, Eberl M, Aberger F. Cooperative Hedgehog-EGFR signaling. Front biosci (Landmark Ed) 2012;17:90-9.

47. Lim SO, Li CW, Xia W, Lee HH, Chang SS, et al. EGFR signaling enhances aerobic glycolysis in triple-negative breast cancer cells to promote tumor growth and immune escape. Cancer Res 2016;76:1284-96.

48. Takebe N, Warren RQ, Ivy SP. Breast cancer growth and metastasis: interplay between cancer stem cells, embryonic signaling pathways and epithelial-to-mesenchymal transition. Breast Cancer Res 2011;13:211.

49. Maltseva DV, Khaustova NA, Fedotov NN, Matveeva EO, Lebedev AE, et al. High-throughput identification of reference genes for research and clinical RT-qPCR analysis of breast cancer samples. J Clin Bioinforma 2013;3:13.

50. Jacquin MA, Chiche J, Zunino B, Bénéteau M, Meynet O, et al. GAPDH binds to active Akt, leading to Bcl-xL increase and escape from caspase-independent cell death. Cell Death Differ 2013;20:1043.

51. Luetteke NC, Lee DC. Transforming growth factor alpha: expression, regulation and biological action of its integral membrane precursor Semin Canc Biol 1990;1:265-75.

52. Geng F, Zhu W, Anderson RA, Leber B, Andrews DW. Multiple post-translational modifications regulate E-cadherin transport during apoptosis. J Cell Sci 2012;125:2615-25.

53. Fang D, Hawke D, Zheng Y, Xia Y, Meisenhelder J, et al. Phosphorylation of B-catenin by AKT promotes B-catenin transcriptional activity. J Biol Chem 2007;282:11221-29. 